\title{
PEMBUATAN MODEL RENCANA STRATEGI PENGEMBANGAN SI/TI DENGAN ZACHMAN FRAMEWORK
}

\author{
Azhar Basir ${ }^{凶}$, Fauzan Ishlakhuddin, Muhammad Syaeful Akbar \\ Program Studi Teknik Informatika, STMIK MPB, Brebes, Indonesia \\ Email: azharbs@stmikmpb.ac.id
}

DOI: https://doi.org/10.46880/jmika.Vol5No2.pp125-134

\begin{abstract}
Organizations need to have IT governance within a certain time frame or commonly referred to as an IT blueprint as a guideline for the organization's strategic planning in designing the needs, development and management of information systems and technology. Sekolah Tinggi Manajemen Informatika dan Komputer (STMIK) Muhammadiyah Paguyangan Brebes is a university that has the view that IS/IT strategic planning is a basic need that can be used to realize the vision and mission. The scope of this research is limited to the academic section (BAA) by dividing the main activities and supporting activities using the value chain, while the enterprise architecture methodology uses the Zachman framework which refers to the first line of the planner's perspective, the second line of the owner's perspective and the data, function and network columns. . This research produces a blueprint for information systems and technology that can be used as a reference in the development of information systems and technology in the 2021-2026 timeframe which has been tested with the results that it is feasible to apply in STMIK-MPB.
\end{abstract}

Keyword: Zachman Framework, Colleges, Information Systems, Technology.

\begin{abstract}
ABSTRAK
Organisasi perlu memiliki tata kelola IT dalam rentan waktu tertentu atau biasa disebut dengan blueprint IT sebagai pedoman perencanaan strategis organisasi dalam merancang kebutuhan, pembangunan dan pengelolaan sistem informasi dan teknologi. Sekolah Tinggi Manajemen Informatika dan Komputer (STMIK) Muhammadiyah Paguyangan Brebes merupakan perguruan tinggi yang memiliki pandangan bahwa pembuatan perencanaan strategis SI/TI merupakan kebutuhan pendasar yang dapat digunakan untuk mewujudkan visi dan misi. Ruang lingkup Penelitian ini dibatasi pada bagian akademik (BAA) dengan membagi aktifitas utama dan aktifitas pendukung menggunakan value chain, sedangkan metodologi enterprise arsitecture menggunakan kerangka kerja zachman framework yang mengacu pada baris pertama perspektif perencana, baris kedua perspektif pemilik serta kolom data, fungsi dan jaringan. Penelitian ini menghasilkan blueprint sistem informasi dan teknologi yang dapat digunakan sebagai acuan dalam pengembangan sistem informasi dan teknologi dalam rentan waktu 2021-2026 yang telah diuji dengan hasil pengujian layak diterapkan di STMIK-MPB.
\end{abstract}

Kata Kunci: Zachman Framework, Perguruan Tinggi, Sistem Informasi, Teknologi.

\section{PENDAHULUAN}

Sistem informasi dan teknologi yang terus berkembang akan berpengaruh pada persaingan antar perguruan tinggi karena perguruan tinggi merupakan organisasi yang memiliki misi sosial yang mengedepankan pada layanan konsumen (Sunardi, Fadlil, \& Fitrian Pahlevi, 2021), perguruan tinggi dituntut untuk terus mengembangkan sistem informasi agar dapat membantu operasi bisnis untuk mencapai tujuan organisasi dari sisi data, informasi sebagai layanan terhadap stakeholder. Data dan informasi yang dikelola dengan baik akan memudahkan dan mempercepat pelayanan serta memperluas jangkauan akses (Fadlil, Riadi, \& Basir, 2021).

Sekolah Tinggi Manajemen Informatika dan Komputer (STMIK) Muhammadiyah Paguyangan Brebes berdiri pada tanggal 28 April 2017 berdasarkan surat keputusan Menteri Riset, Teknologi, dan Pendidikan Tinggi Republik Indonesia Nomor 230/KPT/I/2017. STMIK MPB dalam aktifitas utamanya yaitu pelayanan akademik belum memiliki perencanaan strategis sistem informasi sebagai acuan dalam pengembangan sistem agar sesuai dengan kebutuhan akademik. 
Kajian penelitian terdahulu yang relevan terhadap pembahasan dilakukan, penelitian-penelitian tersebut yaitu:

Penelitian yang menggunakan kerangka kerja TOGAF ADM dengan metodologi Enterprise Architectur Planning (EAP) dilakukan (Azhar, Abdul, \& Imam, 2019) menghasilkan konseptual Architecture Enterprise yang mencakup arsitektur data, arsitektur aplikasi, dan arsitektur teknologi (Solihin \& Wibisono, 2017), yang menggunakan kerangka kerja Zachman Framework dan metodologi Enterprise Architectur Planning (EAP) penelitian ini menghasilkan cetak biru perencanaan strategik SI/TI yang terpadu sehingga mempermudah manajemen dalam mengendalikan dan mengolah data untuk menghasilkan informasi yang dibutuhkan oleh semua pihak. Penelitian yang dilakukan (Riadi, Yanto, \& Handoyo, 2020) berjudul analisis keamanan siber layanan akademik kombinasi kerangka kerja COBIT 5 di domain DSS05 menggunakan PEGI metode dalam layanan keamanan informasi akademik mampu memberikan tingkat pencapaian berupa Nilai Pelanggan. Hasil COBIT 5 analisis kerangka domain DSS05 menggunakan metode PEGI mendapatkan skor sebesar 3,50 sehingga kualitas evaluasi keamanan layanan informasi akademik memiliki pencapaian dengan level sangat baik.

Penelitian ini penulis akan membuat model Rencana Strategi Pengembangan SI/TI dengan menggunakan kerangka kerja Zachman Framework pada Lembaga Pendidikan tinggi diwilayah brebes selatan yaitu STMIK Muhammadiyah Paguyangan Brebes, yang saat ini belum memiliki blueprint SI/TI.

\section{TINJAUAN PUSTAKA}

\section{Strategi}

Strategi merupakan cara memandu enterprise pada tujuan utama pengembangan nilai badan usaha, kemampuan manajerial, pertanggungjawaban organisasi, dan sistem administrasi yang dapat dijadikan panduan dalam pembuatan keputusan kebijakan dan operasional pada seluruh tingkatan, dan melewati seluruh lini bisnis enterprise (Sinha, 2019; Stonehouse \& Snowdon, 2007). Joachim Maes menyarankan bahwa penyusunan strategi melibatkan pemilihan serangkaian kegiatan dengan sengaja untuk memberikan campuran nilai yang unik, menargetkan posisi strategis yang unik dari perusahaan (Maes et al., 2016).

\section{Enterprise Architacture}

Arsitektur enterprise digunakan untuk mengambarkan skema untuk membangun sebuah sistem atau kumpulan sistem yang terpadu (Shanks, Gloet, Asadi Someh, Frampton, \& Tamm, 2018; Spewak, 1992). Organisasi perlu memiliki arsitektur enterprise dengan adanya arsitektur enterprise akan dapat meyujudkan kesesuian antara kebutuhan bisnis dan teknologi informasi (Sandi, Soedijono, \& Nasiri, 2021). Perencanaan arsitektur terbagi menjadi tiga jenis yaitu arsitektur data, arsitektur aplikasi dan arsitektur teknologi (Defriani \& Gito Resmi, 2019).

\section{Zachman Framework}

Zachman Framework merupakan skenario untuk mengelompokkan organisasi, bagian pada Zachman Framework terdiri dari 6 kolom dan 6 baris. Yang terdiri dari perspektif dan focus (Tannady, Andry, Sudarsono, \& Krishartanto, 2020).

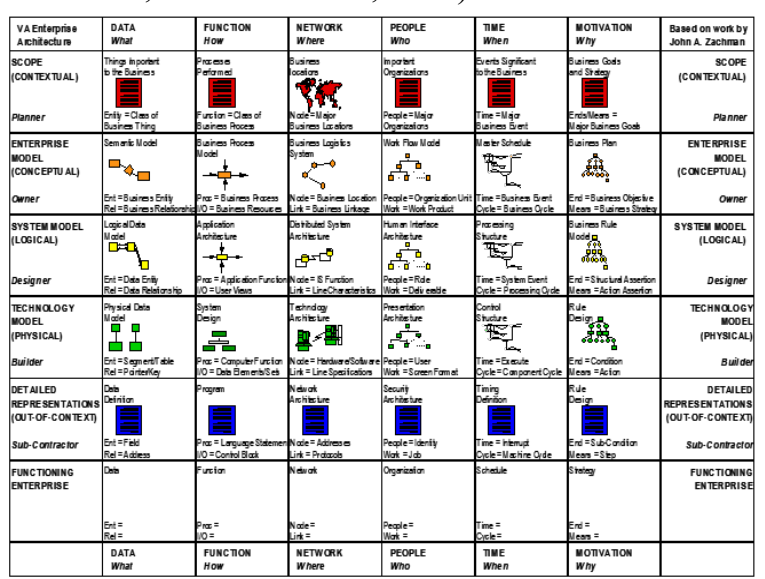

Gambar 1. Zachman Framework

Perspektif menginterpretasikan sudut pandang atau tingkat representasi dari informasi yang terdapat dalam suatu sel yang ada pada kerangka kerja Zachman Framework. Perspektif terdiri dari perspektif perencana, perspektif pemilik, perspektif perancang, perspektif pembangun, Perspektif Subkontraktor, dan Perspektif Fungsional, sedangkan Focus yang terdapat pada kolom zachman framework dapat diidentifikasi dengan pertanyaan di mana, siapa, kapan dan kenapa.

\section{METODE PENELITIAN}

Pengumpulan data pada penelitian ini dilakukan dengan metode kualitatif yaitu:

1. Wawancara dilakukan dengan menggunakan Teknik Focus Group Discussion (FGD), FGD atau diskusi kelompok yang dilakukan secara sistematis 
dan terarah tentang suatu permasalahan (Rizal \& Bisjoe, 2018).

2. Observasi dilakukan dengan melakukan peninjauan terhadap objek penelitian secara langsung untuk memperoleh data yang dibutuhkan dalam proses penelitian (Anufia \& Alhamid, 2019).

\section{HASIL DAN PEMBAHASAN}

\section{Memahami Kondisi Saat Ini}

Hal yang pertama dilakukan dalam pembuatan EA pada Biro Administrasi Akademik yaitu dengan melakukan inisiasi perencanaan. Dengan melakukan inisiasi perencanaan dapat diketahui kondisi proses bisnis yang ada di bidang akademik saat ini. Hal pertama adalah pencarian data proses bisnis yang mencakup seluruh aktivitas dalam bentuk tugas pokok dan fungsi, deskripsi tugas yang ditunjukan pada tabel 1 serta struktur organisasi, kemudian berlanjut pada tahap prosedur, alur kerja, dan fungsi bisnis yang ditunjukan pada tabel 2 .

Tabel 1. Tugas Pokok Biro Akademik

\begin{tabular}{|c|c|c|}
\hline \multirow{5}{*}{$\begin{array}{l}\text { Urusan } \\
\text { evaluasi dan } \\
\text { transaksi } \\
\text { akademik }\end{array}$} & 1 & $\begin{array}{l}\text { melakukan pelayanan } \\
\text { administrasi pindah kuliah, cuti } \\
\text { kuliah, pengunduran diri mahasiswa. }\end{array}$ \\
\hline & 2 & $\begin{array}{l}\text { Melaksanakan layanan administrasi } \\
\text { Kartu Rencana Studi (KRS) } \\
\text { Mahasiswa. }\end{array}$ \\
\hline & 3 & $\begin{array}{l}\text { Melaksanakan layanan penjadwalan } \\
\text { kuliah dan ujian }\end{array}$ \\
\hline & 4 & $\begin{array}{l}\text { Mengkoordinasikan, mengawasi, dan } \\
\text { menyusun laporan semester dan } \\
\text { EPSBED. }\end{array}$ \\
\hline & 5 & $\begin{array}{l}\text { Mengawasi dan memberi catatan } \\
\text { status akademik mahasiswa dalam } \\
\text { program evaluasi masa studi. }\end{array}$ \\
\hline \multirow{4}{*}{$\begin{array}{l}\text { Urusan } \\
\text { dokumentasi } \\
\text { dan } \\
\text { database } \\
\text { akademik }\end{array}$} & 1 & $\begin{array}{l}\text { Menyelenggarakan Wisuda dan } \\
\text { database lulusan }\end{array}$ \\
\hline & 2 & Megelola penerbitan KTM dan ijasah \\
\hline & 3 & $\begin{array}{l}\text { Menyimpan dokumen mahasiswa } \\
\text { (salinan ijasah SMU, NEM, akte } \\
\text { kelahiran, dll) dan lulusan (transkip, } \\
\text { ijasah, kontak personal). }\end{array}$ \\
\hline & 4 & $\begin{array}{l}\text { Mengarsipkan data registrasi, } \\
\text { penghapusan data mahasiswa, dan } \\
\text { statistic lain. }\end{array}$ \\
\hline
\end{tabular}

Tabel 2. SOP Layanan Akademik

\begin{tabular}{|l|l|l|}
\hline No & No SOP & Nama SOP \\
\hline 1 & BA-SOP (5.1.11) & $\begin{array}{l}\text { SOP Penerimaan Mahasiswa } \\
\text { Baru }\end{array}$ \\
\hline 2 & BA-SOP (5.1.12) & $\begin{array}{l}\text { SOP Registrasi dan } \\
\text { Herregistrasi }\end{array}$ \\
\hline
\end{tabular}

\begin{tabular}{|l|l|l|}
\hline 3 & BA-SOP $(5.1 .16)$ & SOP Perkuliahan \\
\hline 4 & BA-SOP $(5.1 .19)$ & SOP Ujian \\
\hline 5 & BA-SOP $(5.1 .22)$ & SOP Penyusunan Skripsi \\
\hline 6 & BA-SOP $(5.1 .22)$ & SOP Wisuda \\
\hline 7 & BA-SOP $(5.1 .23)$ & SOP Praktikum \\
\hline
\end{tabular}

Aktivitas-aktivitas pelayanan yang ada saat ini sudah di bantu dengan Sistem Informasi Akademik (SIAKAD) yang mendukung penyelenggaraan administrasi akademik, diawali dari penawaran matakuliah, pengambilan studi, penjadwalan, riwayat nilai, absensi perkuliahan, pembayaran perkuliahan, kartu hasil studi, kartu rencana studi, dan hasil studi kumulatif (transkrip). Sistem ini merupakan hasil kerja sama antara STMIKMPB dengan PT. Sentra Widya Utama selaku menyedia SEVIMA GoFeeder. Deskripsi aplikasi SIAKAD dapat dilihat pada Tabel 3.

\section{Analisis Kondisi Saat Ini}

Analisis kondisi saat ini dilakukan untuk menemukan masalah dari sisi yang berbeda dengan menggunakan analisis SWOT. Implementasinya adalah menemukan cara kekuatan (strengths) mampu mendapat keuntungan dari kesempatan (opportunities) yang ada, dan dapat menemukan solusi untuk dapat mengendalikan kelemahan (weaknesses) yang dapat mencegah keuntungan. Selanjutnya memunculkan kekuatan (strengths) yang dapat mencegah ancaman (threats) yang ada, dan terakhir adalah menemukan kelemahan (weaknesses) yang membuat ancaman (threats) menjadi nyata atau menciptakan sebuah ancaman baru.

Tabel 3. Deskripsi Aplikasi Siakad

\begin{tabular}{|l|l|}
\hline \multicolumn{1}{|c|}{ Nama } & \multicolumn{1}{c|}{ Aplikasi SIAKAD } \\
\hline Nama Lengkap & Sistem Informasi Akademik \\
\hline $\begin{array}{l}\text { Penanggung } \\
\text { Jawab/Pengelola }\end{array}$ & $\begin{array}{l}\text { Biro Administrasi Akademik dan } \\
\text { Kemahasiswaan }\end{array}$ \\
\hline Versi & SEVIMA GoFeeder 4.0.4 \\
\hline Tahun pembuatan & 2018 \\
\hline Pembuat & PT. Sentra Widya Utama \\
\hline Deskripsi & $\begin{array}{l}\text { merupakan sistem yang } \\
\text { mensupport penyelenggaraan } \\
\text { administrasi akademik di STMIK } \\
\text { MPB, mulai dari penawaran } \\
\text { matakuliah, penjadwalan, } \\
\text { pengambilan studi, riwayat nilai, } \\
\text { absensi perkuliahan, pembayaran } \\
\text { perkuliahan, kartu hasil studi, } \\
\text { kartu rencana studi, dan hasil studi } \\
\text { kumulatif (transkrip). }\end{array}$ \\
\hline Status Operational & Operasional \\
\hline
\end{tabular}




\begin{tabular}{|l|l|}
\hline \multicolumn{1}{|c|}{ Nama } & \multicolumn{1}{c|}{ Aplikasi SIAKAD } \\
\hline Jenis penggunaan & Online \\
\hline $\begin{array}{l}\text { Mulai } \\
\text { Implementasi } \\
\text { (Aktif) }\end{array}$ & $2018-$ sekarang \\
\hline User Manual & Ada \\
\hline Operating Sistem & Windows 2010 \\
\hline Processor & Core i3 \\
\hline Memory & 4 GB \\
\hline Hard Disk & $500 \mathrm{~GB}$ \\
\hline
\end{tabular}

\section{Rancangan Arsitektur Masa Depan Arsitektur Bisnis}

Tahapan pembuatan model enterprise dilakukan untuk menentukan model bisnis atau aktivitas bisnis yang diharapkan yang didasarkan skenario bisnis (proses bisnis yang ada pada kondisi saat ini). Proses bisnis ini dibantu oleh sistem informasi. Proses bisnis ini diharapkan mampu mendukung sistem informasi yang digunakan pada kegiatan akademik. Proses bisnis

Hasil dari analisis SWOT dapat digunakan untuk dijadikan landasan dalam melakukan peningkatan pelayanan dan perencanaan pengembangan sistem yang dapat menunjang pelayanan akademik yang baik yang berlandaskan hasil yang ada dibiro akademik yaitu penerimaan mahasiswa baru, herregistrasi, perkuliahan, ujian, penyusunan skripsi, yudisium dan praktikum. Gambar 2 merupakan contoh proses bisnis penerimaan mahasiswa baru yang diharapkan. analisis SWOT

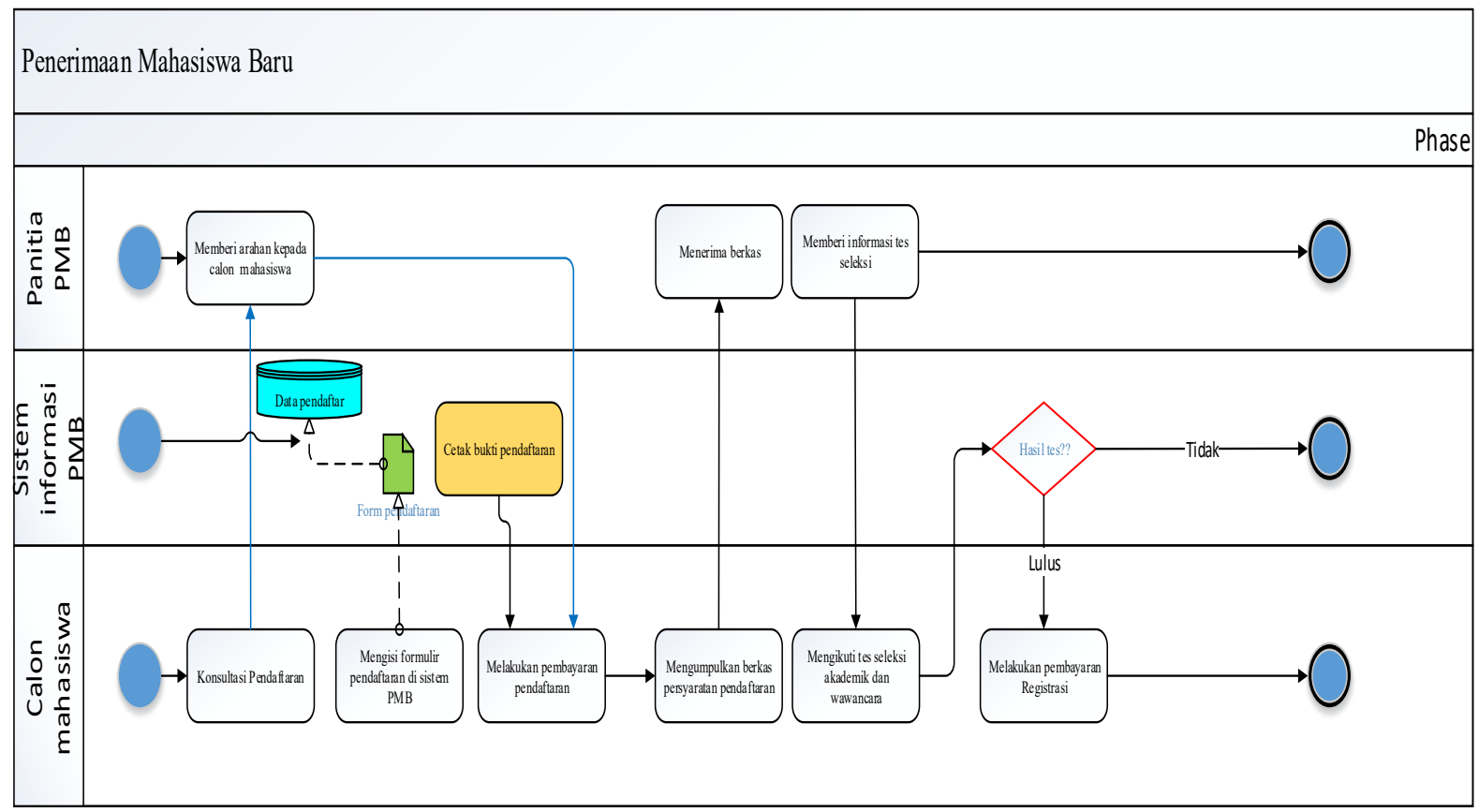

Gambar 2. Proses Bisnis Penerimaan Mahasiswa Baru

\section{Arsitektur Informasi}

Langkah untuk membangun Arsitektur informasi yaitu dengan mengidentifikasi arsitektur data dan arsitektur aplikasi.

\section{Arsitektur Data}

Keterikatan antar entitas data digunakan untuk menyusun arsitektur data untuk melandasi pembangunan arsitektur enterprise. Antar entitas data disusun sesuai dengan hubungan dalam konteks area fungsi didukungnya. Pemodelan dibuat dengan ERD yang merupakan model yang dibuat terdiri dari koleksi obyek-obyek dasar yang dinamakan entitas (entity) serta menggambarkan hubungan (relasi) antar entitas yang digunakan. Rancangan ERD pada kegiatan akademik terbagi menjadi enam, yaitu PMB, Herregistrasi, pelaksanaan perkuliahan, Ujian, Penyusunan Skripsi, dan Praktikum 
Langkah selanjutnya untuk mendefinisikan arsitektur data, yaitu membuat metrik proses vs entitas data. Matriks yang merealisasikan antara entitas data dengan fungsi bisnis dapat digunakan untuk mengembangkan ruang lingkup aplikasi pada tahapan selanjutnya dan untuk menunjukkan data sharing pada bisnis. Berdasarkan kebutuhan data dari masingmasing sistem ditentukan aliran data yang dapat mendefinisikan hubungan antar sistem. Dengan demikian dapat didefinisikan arsitektur informasi. Tabel 5 merupakan contoh dari metrik proses bisnis dengan entitas data penerimaan mahasiswa baru.

Berdasarkan arsitektur informasi yang dihasilkan maka dapat diidentifikasi sistem-sistem utama yang dikembangkan berdasarkan pengelompokan dari PMB, Pelayanan Herregistrasi, Persiapan perkuliahan, Pelaksanaan Kuliah, Evaluasi Kuliah, Persiapan Ujian, Selesai Ujian, Evaluasi Ujian, Persiapan Praktikum, Pelaksanaan Praktikum, Evaluasi Praktikum, Pengelolaan Skripsi, dan Yudisium.

\section{Arsitektur Aplikasi}

Tujuan dari Arsitektur aplikasi adalah untuk membantu fungsi bisnis utama organisasi. Hal pertama untuk mendefinisikan aplikasi yang dibutuhkan oleh organisasi diantaranya adalah menentukan kandidat aplikasi, menghubungkan aplikasi dengan fungsi bisnis yang telah didefinisikan, dan menghubugkan aplikasi dengan unit organisasi. Merancang arsitektur aplikasi diawali dengan menelaah kandidat aplikasi yang digunakan untuk mengelola data dan mendukung proses bisnis yang dapat dipermudah dengan adannya teknologi informasi. Entitas data diperlihatkan untuk Identifikasi kandidat aplikasi, proses bisnis dan catatan yang telah ditetapkan sebelumnya sebagai sumber daya informasi. Aplikasi-aplikasi yang diperlukan untuk mendukung fungsi bisnis dapat dikelompokkan kedalam suatu sistem informasi fungsional dan diberi nama sesuai dengan fungsi yang didukungnya. Tabel 4 merupakan kandidat aplikasi pada penerimaan mahasiswa baru STMIKMPB. Hubungan aplikasi vs organisasi terdapat pada tabel 6 .

Tabel 4. Kadidat Aplikasi PMB

\begin{tabular}{|c|c|c|c|c|}
\hline 离 & Kelompok Sistem & No Kandidat Aplikasi & Deskripsi & Keterangan \\
\hline \multirow{7}{*}{ 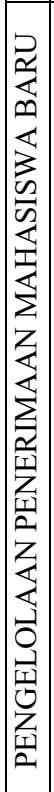 } & \multirow{7}{*}{$\begin{array}{l}\text { Sistem informasi } \\
\text { penerimaan } \\
\text { mahasiswa baru }\end{array}$} & $\begin{array}{l}1.1 \\
\text { Sistem penentuan } \\
\text { daya tampung }\end{array}$ & $\begin{array}{l}\text { Berisi jumlah kelas yang bisa digunakan dan rasio dosen } \\
\text { yang tersedia yang bisa dijadikan pedoman pimpinan } \\
\text { STMIK-MPB untuk menentukan kebijakan }\end{array}$ & $\begin{array}{l}\text { Pengembangan } \\
\text { baru }\end{array}$ \\
\hline & & $\begin{array}{l}1.2 \text { Sistem pengelolaan } \\
\text { pantia PMB }\end{array}$ & $\begin{array}{l}\text { Menampilkan daftar panitia PMB, dan proses pendaftaran } \\
\text { panitia dari kalangan mahasiswa, serta agenda dari panitia } \\
\text { PMB }\end{array}$ & $\begin{array}{l}\text { Penge } \\
\text { baru }\end{array}$ \\
\hline & & $\begin{array}{l}1.3 \text { Sistem pengelolaan } \\
\text { promosi dan } \\
\text { sosialisasi }\end{array}$ & $\begin{array}{l}\text { Menampilkan daftar kegiatan promisi dan sosialisasi, } \\
\text { serta jadwal kegiatanya }\end{array}$ & $\begin{array}{l}\text { Pengembangan } \\
\text { baru }\end{array}$ \\
\hline & & $\begin{array}{l}1.4 \text { Sistem pendaftaran } \\
\text { calon mahasiswa }\end{array}$ & $\begin{array}{l}\text { Menampilkan form pendaftaran, informasi proses seleksi, } \\
\text { informasi pembayaran dan agenda PMB lainya }\end{array}$ & $\begin{array}{l}\text { Pengembangan } \\
\text { baru }\end{array}$ \\
\hline & & $\begin{array}{l}1.5 \text { Sistem pengelolaan } \\
\text { pendaftaran calon } \\
\text { mahasiswa }\end{array}$ & $\begin{array}{l}\text { Menampilkan daftar calon mahasiswa, asal sekolah, } \\
\text { alamat no tlp persyaratan yang sudah dan belum } \\
\text { terpenuhi dan tahapan yang sudah dilakukan. }\end{array}$ & $\begin{array}{l}\text { Pengembangan } \\
\text { baru }\end{array}$ \\
\hline & & $\begin{array}{l}\text { 1.6 } \begin{array}{l}\text { Sistem seleksi calon } \\
\text { mahasiswa }\end{array} \\
\text { ahis }\end{array}$ & Menampilkan soal tes potensi akademik & $\begin{array}{l}\text { Pengembangan } \\
\text { baru }\end{array}$ \\
\hline & & $\begin{array}{l}\text { 1.7 } \\
\text { Sistem evaluasi } \\
\text { penerimaan } \\
\text { mahasiswa baru }\end{array}$ & $\begin{array}{l}\text { Menampilkan daftar calon mahasiswa dari asal } \\
\text { sekolah/lembaga, alamat, tempat promosi dan sosialisasi. } \\
\text { Dan menampilkan statistik penerimaan mahasiswa baru }\end{array}$ & $\begin{array}{l}\text { Pengembangan } \\
\text { baru }\end{array}$ \\
\hline
\end{tabular}


Tabel 5. Metrik Proses Bisnis vs Entitas Data PMB

\begin{tabular}{|c|c|c|c|c|c|c|c|c|c|}
\hline \multicolumn{10}{|c|}{ Metrik proses bisnis vs entitas data PMB } \\
\hline \multicolumn{2}{|l|}{ Proses } & 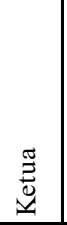 & 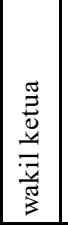 & $\begin{array}{l}ت \bar{Z} \\
0 \\
\tilde{a} \\
\tilde{J}\end{array}$ & 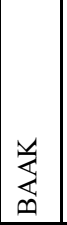 & 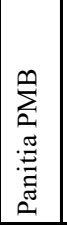 & 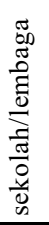 & 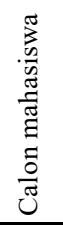 & 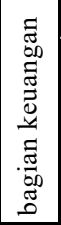 \\
\hline \multirow{5}{*}{ 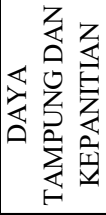 } & usulan daya tampung calon mahasiswa & UR & UR & CUR & CUR & & & & \\
\hline & menentukan daya tampung yang akan diajukan & UR & CUR & $\mathrm{R}$ & $\mathrm{R}$ & & & & \\
\hline & menyetujui daya tampung & CUR & $\mathrm{R}$ & $\mathrm{R}$ & $\mathrm{R}$ & & & & \\
\hline & membentuk kepanitian PMB & UR & CUR & UR & $\mathrm{R}$ & & & & \\
\hline & SK kepanitian PMB & CUR & $\mathrm{R}$ & $\mathrm{R}$ & $\mathrm{R}$ & & & & \\
\hline \multirow{10}{*}{ 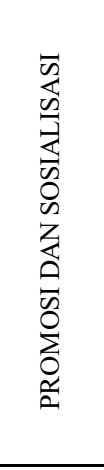 } & menentukan target dan strategi promosi dan sosialisasi & & CUR & & & & & & \\
\hline & Input data informasi penerimaan mahas is wa baru & UR & UR & UR & UR & CUR & & & \\
\hline & Memposting informasi PMB di sosial media resmi STMIK-MPB & & UR & UR & UR & CUR & & & \\
\hline & $\begin{array}{l}\text { Menghubungi sekolah/lembaga yg menjadi target promosi dan } \\
\text { sosialisasi }\end{array}$ & $\mathrm{R}$ & $\mathrm{R}$ & $\mathrm{R}$ & $\mathrm{R}$ & CUR & UR & & \\
\hline & Pelaksanaan sosialisasi di sekolah dan lembaga-lembaga lain & & $\mathrm{R}$ & $\mathrm{R}$ & $\mathrm{R}$ & CUR & & & \\
\hline & Mengikuti Event/Kegiatan untuk promosi & & $\mathrm{R}$ & $\mathrm{R}$ & $\mathrm{R}$ & CUR & & & \\
\hline & Membuat laporan kegitan promosi dan sosialisasi & & UR & $\mathrm{R}$ & $\mathrm{R}$ & CUR & & & \\
\hline & Evaluasi promosi dan sosialisasi berdasarkan hasil PMB & $\mathrm{R}$ & CUR & $\mathrm{R}$ & $\mathrm{R}$ & UR & & & \\
\hline & Membuat laporan evaluasi kegiatan promosi dan sosialisasi & & CUR & UR & UR & UR & & & \\
\hline & Menentukan tindakan hasil evaluasi & CUR & UR & UR & UR & $\mathrm{R}$ & & & \\
\hline \multirow{7}{*}{ 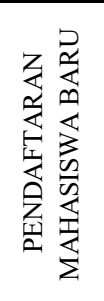 } & Konsultasi Pendaftaran & & $\mathrm{R}$ & $\mathrm{R}$ & $\mathrm{R}$ & UR & & CUR & \\
\hline & Mengis i formulir pendaftaran di sistem PMB & & & & & UR & & CUR & \\
\hline & Melakukan pembayaran pendaftaran & & $\mathrm{R}$ & $\mathrm{R}$ & $\mathrm{R}$ & UR & & CUR & CUR \\
\hline & Mengumpulkan berkas pendaftaran & & UR & UR & UR & CUR & & CUR & \\
\hline & Memberi informasi tes seleksi & & & & & CUR & & UR & \\
\hline & Mengikuti tes seleksi akademik dan wawancara & & UR & UR & UR & UR & & CUR & \\
\hline & Melakukan pembayaran Regis trasi & & UR & UR & UR & $\mathrm{R}$ & & CUR & CUR \\
\hline
\end{tabular}

Tabel 6. Aplikasi vs Organisasi

\begin{tabular}{|c|c|c|c|c|c|c|c|c|c|c|c|c|c|c|c|c|}
\hline & Unit Organisasi & $\underset{\tilde{D}}{\tilde{D}}$ & $\begin{array}{l}\frac{\pi}{3} \\
\frac{0}{0} \\
\frac{1}{\pi} \\
\frac{\pi}{3} \\
3\end{array}$ & 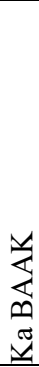 & 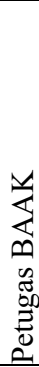 & 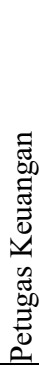 & 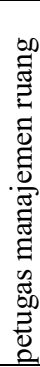 & 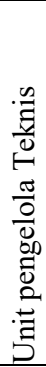 & $\begin{array}{l}\bar{z} \\
\bar{z} \\
\tilde{g} \\
\underline{z}\end{array}$ & 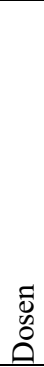 & $\frac{0}{\sqrt[0]{2}}$ & 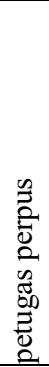 & 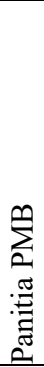 & 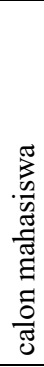 & 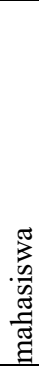 & $\sum^{\circledR}$ \\
\hline 1 & Sistem penentuan daya tampung & $\mathbf{x}$ & $\mathbf{x}$ & $\mathbf{x}$ & & & & & $\mathbf{x}$ & & & & & & & 4 \\
\hline 2 & sistem pengelolaan panitia $\mathrm{PMB}$ & & & $\mathbf{x}$ & $\mathbf{x}$ & & & & $\mathbf{x}$ & & & & & & & 3 \\
\hline 3 & $\begin{array}{l}\text { Sistem pengelolaan promosi dan } \\
\text { sosialisasi }\end{array}$ & & $\mathbf{x}$ & & $\mathbf{x}$ & & & & $\mathbf{x}$ & & & & $\mathbf{x}$ & & & 4 \\
\hline 4 & Sistem pendaftaran calon mahasiswa & & & & $\mathbf{x}$ & $\mathbf{x}$ & & & $\mathbf{x}$ & & & & $\mathbf{x}$ & & & 4 \\
\hline 5 & $\begin{array}{l}\text { Sistem pengelolaan pendaftaran calon } \\
\text { mahasiswa }\end{array}$ & & $\mathbf{x}$ & $\mathbf{x}$ & $\mathbf{x}$ & & & & $\mathbf{x}$ & & & & & & & 4 \\
\hline 6 & Sistem seleksi calon mahasiswa & & $\mathbf{x}$ & & $\mathbf{x}$ & & & & & & & & & $\mathbf{x}$ & & 3 \\
\hline 7 & $\begin{array}{l}\text { Sistem evaluasi penerimaan } \\
\text { mahasiswa baru }\end{array}$ & $\mathbf{x}$ & $\mathbf{x}$ & $\mathbf{x}$ & & & & & $\mathbf{x}$ & & & & & & & 4 \\
\hline
\end{tabular}


Tabel 7. Prinsip dan Platfirm Teknologi

\begin{tabular}{|c|c|c|c|}
\hline No & Kelompok & No & Prinsip \\
\hline \multirow{5}{*}{1} & \multirow{5}{*}{$\begin{array}{l}\text { Perangkat keras (jenis } \\
\text { komputer, perangkat } \\
\text { input/output dan media } \\
\text { simpanan) }\end{array}$} & 1.1 & $\begin{array}{l}\text { Mendukung upgrade sistem ke tipe/model yang lebih tinggi dari storage yang } \\
\text { ditawarkan dengan tetap menjaga investasi yang telah ada (tidak diperlukan } \\
\text { proses backup restore terhadap data yang ada) }\end{array}$ \\
\hline & & 1.2 & $\begin{array}{l}\text { Perangkat keras andal untuk mendukung bisnis saat ini dan mampu } \\
\text { beradaptasi terhadap perkembangan teknologi di masa mendatang sehingga } \\
\text { tidak cepat usang (obsolete) }\end{array}$ \\
\hline & & 1.3 & $\begin{array}{l}\text { Perangkat keras dapat mensuport kebutuhan akan efisiensi dan efektivitas } \\
\text { kerja }\end{array}$ \\
\hline & & 1.4 & Perangkat keras dapat mendukung teknologi client-server \\
\hline & & 1.5 & $\begin{array}{l}\text { Mendukung sistem operasi: Microsoft Windows, IBM AIX, Sun Solaris, HP- } \\
\text { UX, Linux, dan VMware }\end{array}$ \\
\hline \multirow{14}{*}{2} & \multirow{14}{*}{$\begin{array}{l}\text { Perangkat lunak (sistem } \\
\text { operasi, sistem pengelola } \\
\text { basis data/DBMS, bahasa } \\
\text { pemrograman) }\end{array}$} & 2.1 & Perangkat lunak mendukung teknologi client-server \\
\hline & & 2.2 & Penggunaan bandwidth seminimum mungkin \\
\hline & & 2.3 & $\begin{array}{l}\text { Sistem operasi dapat beroperasi pada berbagai platform dari berbagai vendor ( } \\
\text { portabel), dapat diterapkan pada berbagai jenis komputer (scalable), dapat } \\
\text { beroperasi pada lingkungan yang heterogen (interoperable ) dan dapat } \\
\text { memepertahanlan investasi perangkat lunak saat ini dan mampu mendukung } \\
\text { integrasi dengan komponen teknologi yang lebih maju (compatible). }\end{array}$ \\
\hline & & 2.4 & $\begin{array}{l}\text { Sistem operasi dapat mendukung tool pengembangan sistem dan beragam } \\
\text { perangkat lunak aplikasi }\end{array}$ \\
\hline & & 2.5 & $\begin{array}{l}\text { DBMS harus mampu mengakomodasi kebutuhan dan transaksi data dengan } \\
\text { toleransi terhadap kegagalan yang baik }\end{array}$ \\
\hline & & 2.6 & Sistem Operasi dapat digunakan diberbagai Browser. \\
\hline & & 2.7 & $\begin{array}{l}\text { Spesifikasi Platform \& Database harus mendukung clustering \& balancing, } \\
\text { mendukung Replication serta mendukung Integrasi }\end{array}$ \\
\hline & & 2.8 & Tidak dapat menyimpan data yang sama (redudensi data) \\
\hline & & 2.9 & $\begin{array}{l}\text { Data tersimpan secara terpusat dan bisa digunakan diberbagai lokasi serta } \\
\text { harus tetap konsisten }\end{array}$ \\
\hline & & 2.10 & $\begin{array}{l}\text { Informasi update secara berkala, tersimpan secara online dan tersedia secara } \\
\text { terus menerus. }\end{array}$ \\
\hline & & 2.11 & Adanya pembatasan hak akses terhadap data dan aplikasi. \\
\hline & & 2.12 & Data harus mudah dipelihara, di-backup dengan dukungan teknologi \\
\hline & & 2.13 & $\begin{array}{l}\text { Bahasa pemrograman mendukung mendukung teknik pengembangan } \\
\text { berorientasi objek dan metode information engineering }\end{array}$ \\
\hline & & 2.14 & $\begin{array}{l}\text { Bahasa pemrograman dapat menghasilkan aplikasi yang bersifat graphical } \\
\text { user interfacr (GUI) }\end{array}$ \\
\hline \multirow{6}{*}{3} & \multirow{6}{*}{ Komunikasi } & 3.1 & $\begin{array}{l}\text { Teknologi jaringan harus mampu mendukung teknologi client-server dan } \\
\text { Protokol komunikasi berstandar internasional }\end{array}$ \\
\hline & & 3.2 & $\begin{array}{l}\text { Koneksi client - server menggunakan konsep VPN yang berfungsi sebagai } \\
\text { infrastuktur sinkronisasi data antara cabang dan pusat yang menggunakan } \\
\text { topologi Transaksional dan Snapshot model. }\end{array}$ \\
\hline & & 3.3 & $\begin{array}{l}\text { Teknologi jaringan dapat disesuaikan dengan perkembangan teknologi ke } \\
\text { depan dan dapat menunjang aktivitas bisnis saat ini. }\end{array}$ \\
\hline & & 3.4 & Jaringan mampu menangani beragam format aplikasi dan data \\
\hline & & 3.5 & Bandwidth yang memadai untuk pengaksesan data \\
\hline & & 3.6 & $\begin{array}{l}\text { Router memiliki minimal } 2 \text { port 10/100/1000 dan mempunyai } 2 \text { modular } \\
\text { interface slot }\end{array}$ \\
\hline
\end{tabular}




\begin{tabular}{|c|c|c|c|}
\hline & & 3.7 & $\begin{array}{l}\text { Router mendukung WAN protokol : PPP, MLPPP, Frame Relay, HDLC, } \\
\text { PPPoE }\end{array}$ \\
\hline & & 3.8 & Core Switch mempunyai fitur Routing Ipv4 dan Ipv6 \\
\hline & & 3.9 & Teknis Storage mempunyai arsitektur Storage Area Network (SAN) \\
\hline \multirow{7}{*}{4} & \multirow{7}{*}{ Keamanan } & 4.1 & $\begin{array}{l}\text { Mempunyai fitur keamanan Firewall, IPS, Antivirus, AntiSpam, Application } \\
\text { Control, DLP dan Web Content Filtering }\end{array}$ \\
\hline & & 4.2 & Mempunyai fitur virtual sistem minimal 8 Virtual Sistem \\
\hline & & 4.3 & Mempunyai fitur HighAvailability Active-Active/Active Passive \\
\hline & & 4.4 & Dapat berjalan sebagai mode Inline (bridging) ataupun Route mode \\
\hline & & 4.5 & Mempunyai Port modularity \\
\hline & & 4.6 & Mempunyai Redundant Power Supply \\
\hline & & 4.7 & Mempunyai User License yang tidak terbatas. \\
\hline
\end{tabular}

Tabel 8. Daftar Aplikasi

\begin{tabular}{|c|c|c|c|}
\hline No & Nama Aplikasi & No & Nama Aplikasi \\
\hline 1 & Sistem pengelolaan Rencana studi & 32 & Sistem pengajuan pembuatan KTM Pengganti \\
\hline 2 & Sistem pengelolaan sarana prasarana & 33 & Sistem rekapitulasi pembayaran SPP \\
\hline 3 & Sistem pengelolaan Evaluasi Studi & 34 & Sistem cek Info Pembayaran \\
\hline 4 & Sistem putus studi/gugur studi & 35 & Sistem cek Mata kuliah ditawarkan \\
\hline 5 & Sistem cuti akademik & 36 & $\begin{array}{l}\text { Sistem dokumentasi perwalian dengan dosen persiapan } \\
\text { kuliah }\end{array}$ \\
\hline 6 & Sistem pengelolaan pengunduran diri & 37 & Sistem pengisian kuisioner penilaian dosen \\
\hline 7 & Sistem pengelolaan rekap data KTM & 38 & Sistem cetak kartu ujian portal mahasiswa \\
\hline 8 & $\begin{array}{l}\begin{array}{l}\text { Sistem pengelolaan pelaporan kegiatan } \\
\text { herregistrasi }\end{array} \\
\end{array}$ & 39 & Sistem jadwal ujian mahasiswa \\
\hline 9 & sistem dokumentasi konsultasi dengan dosen & 40 & Sistem input nilai akhir \\
\hline 10 & Sistem pegelolaan RPS dan handout bahan ajar & 41 & Sistem KHS \\
\hline 11 & Sistem Pengelolaan Dosen & 42 & Sistem transkip nilai \\
\hline 12 & Sistem Manajemen Ruang & 43 & Sistem penentuan daya tampung \\
\hline 13 & Sistem pengelolaan kurikulum & 44 & Sistem pengelolaan pantia PMB \\
\hline 14 & Sistem setting bimbingan & 45 & Sistem pengelolaan promosi dan sosialisasi \\
\hline 15 & Sistem pengelolaan data bimbingan akademik & 46 & Sistem pendaftaran calon mahasiswa \\
\hline 16 & Sistem pendaftaran KRS online & 47 & Sistem pengelolaan pendaftaran calon mahasiswa \\
\hline 17 & Sistem pengelolaan presensi kuliah mhs & 48 & Sistem seleksi calon mahasiswa \\
\hline 18 & Sistem presensi Dosen & 49 & Sistem evaluasi penerimaan mahasiswa baru \\
\hline 19 & Sistem cek presensi & 50 & Sistem Manajemen ruang Lab \\
\hline 20 & Sistem pengelolaan Laporan perkuliahan & 51 & Sistem Penjadwalan Praktikum \\
\hline 21 & Sistem pengelolaan pengawas ujian & 52 & Sistem info praktikum \\
\hline 22 & Sistem jadwal pengawas dan dosen & 53 & Sistem pengelolaan materi praktikum \\
\hline 23 & Sistem pengelolaan hasil studi & 54 & Sistem pengelolaan nilai praktikum \\
\hline 24 & Sistem pengelolaan kuisioner penilaian dosen & 55 & Sistem rekapitulasi presensi praktikum \\
\hline 25 & Sistem pengelolaan transkip nilai & 56 & Sistem laporan hasil evaluasi praktikum \\
\hline 26 & Sistem pengelolaan dosen pembimbing & 57 & Sistem verifikasi bukti bebas perpustakaan \\
\hline 27 & $\begin{array}{l}\text { Sistem pendaftaran seminar proposal Tugas } \\
\text { Akhir }\end{array}$ & 58 & Sistem statistik dan rekapitulasi herregistrasi mahasiswa \\
\hline 28 & Sistem pendaftaran pendadaran Tugas Akhir & 59 & Sistem statistik dan rekapitulasi Dosen \\
\hline
\end{tabular}




\begin{tabular}{|c|l|l|l|}
\hline No & \multicolumn{1}{|c|}{ Nama Aplikasi } & No & \multicolumn{1}{|c|}{ Nama Aplikasi } \\
\hline 29 & Sistem pengelolaan syarat yudisium & 60 & Sistem statistik dan rekapitulasi Mahasiswa \\
\hline 30 & Sistem pengajuan cuti akademik & 61 & Sistem statistik dan rekapitulasi Presensi \\
\hline 31 & Sistem pengajuan pengunduran diri & 62 & Sistem statistik dan rekapitulasi Evaluasi \\
\hline
\end{tabular}

\section{Arsitektur Teknologi}

Arsitektur teknologi manjadi kebutuhan inti yang perlu tersedia sebagai sarana jalannya data dan aplikasi yang digunakan oleh organisasi.Arsitektur teknologi mendefiniskan kebutuhan teknologi yang perlu disediakan di lingkungan bisnis untuk menjalam arsitektur data yang dapat mengelola data berdasarkan asitektur aplikasi, sehingga bisa dikatakan arsitektur teknologi merupakan kebutuhan instruktur yang harus disediakan untuk mendukung jalannya data dan aplikasi yang digunakan oleh organisasi. prinsip dan platform diidentifikasi untuk mendukung jalannya data dan aplikasi yang telah diidentifikaasi sebelumnya. Prinsip dan platform teknologi dapat dilihat pada tabel 7. Tahapan selanjutnya dalam membangun arsitektur teknologi yaitu dengan membangun topologi jaringan topologi yang dibangun memperhatikan pengadaan data warehouse sebagai upaya dalam mempermudah dalam pengambilan keputusan bagi pihak eksekutif. konsep data warehouse yang dibuat dapat digunakan sebagai solusi penyimpanan data pengelolaan data historis yang lebih baik, penyimpanan data dalam data warehouse diletakan dalam basis data yang berbeda dengan penyimpanan data operasional sehari-hari agar tidak membebani proses On Line Transaction Processing (OLTP).

\section{KESIMPULAN}

Berdasarkan langkah-langkah yang sudah dilakukan dapat disimpulkan. Blueprint SI/TI yang dihasilkan dapat membantu jalannya proses bisnis akademik, arsitektur data, arsitektur aplikasi dan arsitektur teknologi yang dihasilkan dalam penelitian ini saling terkait sehingga dapat memudahkan dalam pengelolaan, penyampaian data dan informasi.

\section{DAFTAR PUSTAKA}

Anufia, B., \& Alhamid, T. (2019). Instrumen Pengumpulan Data. Jurnal Sekolah Tinggi Agama Islam Negeri (STAIN) Sorong, 1(1), 120.

Azhar, B., Abdul, F., \& Imam, R. (2019). Enterprise Architecture Planning Sistem Informasi Akademik Dengan TOGAF ADM. J-SAKTI (Jurnal Sains Komputer Dan Informatika), 3(1),
1. https://doi.org/10.30645/j-sakti.v3i1.91

Defriani, M., \& Gito Resmi, M. (2019). Analisis Arsitektur E-government dengan Menggunakan Kerangka Kerja Federal Enterprise Architecture ( FEA ). Konferensi Nasional SNIA 2019, 3(2), $1-16$.

Fadlil, A., Riadi, I., \& Basir, A. (2021). Integration of Zachman Framework and TOGAF ADM on Academic Information Systems Modeling. INTENSIF: Jurnal Ilmiah Penelitian Dan Penerapan Teknologi Sistem Informasi, 5(1), 72-85.

https://doi.org/10.29407/intensif.v5i1.14678

Maes, J., Liquete, C., Teller, A., Erhard, M., Paracchini, M. L., Barredo, J. I., ... Lavalle, C. (2016). An indicator framework for assessing ecosystem services in support of the EU Biodiversity Strategy to 2020. Ecosystem Services, 17(1), 14-23. https://doi.org/10.1016/j.ecoser.2015.10.023

Riadi, I., Yanto, I. R., \& Handoyo, E. (2020). Cyber Security Analysis of Academic Services based on Domain Delivery Services and Support using Indonesian E-Government Ratings (PEGI). Kinetik: Game Technology, Information System, Computer Network, Computing, Electronics, and Control, (December), 263-270. https://doi.org/10.22219/kinetik.v5i4.1083

Rizal, A., \& Bisjoe, H. (2018). Menjaring Data dan informasi penelitian melalui Focus Group Discussion (FGD ): Belajar dari Praktek Lapangan. Info Teknis EBONI, Vol. 15 No, 1728.

Sandi, A. S., Soedijono, B., \& Nasiri, A. (2021). Pengaruh Kegunaan dan Kemudahan Terhadap Sikap Penggunaan Dengan Metode TAM Pada Sistem Informasi Magang. IT Journal Research and Development (ITJRD), 5(2), 109-117.

Shanks, G., Gloet, M., Asadi Someh, I., Frampton, K., \& Tamm, T. (2018). Achieving benefits with enterprise architecture. Journal of Strategic Information Systems, 27(2), 139-156. https://doi.org/10.1016/j.jsis.2018.03.001

Sinha, S. (2019). The emergent-strategy process of initiating organizational ambidexterity. Journal of Strategy and Management, 12(3), 382-396. https://doi.org/10.1108/JSMA-12-2018-0140

Solihin, I. P., \& Wibisono, M. B. (2017). Desain Kebijakan Sistem Informasi dan Teknologi Informasi Dengan Framework Zachman Pada Perguruan Tinggi Negeri Baru di Jakarta. Jurnal 
RESTI (Rekayasa Sistem Dan Teknologi Informasi), 1(3), 266-276.

https://doi.org/10.29207/resti.v1i3.83

Spewak, S. H. (1992). Enterprise Architecture Planning (Developng a Blueprint for Data, Application and Technology),. John Wiley \& Sons, Inc.

Stonehouse, G., \& Snowdon, B. (2007). Competitive advantage revisited Michael Porter on strategy and competitiveness. Journal of Management Inquiry, 16(3), 256-273.

https://doi.org/10.1177/1056492607306333

Sunardi, Fadlil, A., \& Fitrian Pahlevi, R. (2021). Pengambilan Keputusan Sistem Penjaminan Mutu Perguruan Tinggi menggunakan MOORA, SAW, WP, dan WSM. Jurnal RESTI (Rekayasa Sistem Dan Teknologi Informasi), 5(2), 350 358. https://doi.org/10.29207/resti.v5i2.2977

Tannady, H., Andry, J. F., Sudarsono, B. G., \&

Krishartanto, Y. (2020). Enterprise-

Architecture-Using-Zachman-Framework-At-

Paint-Manufacturing-Company-

5Ed2Ac9005Dac-1. 62(04), 1869-1883. 